\title{
THE PHYSICIANS DISCIPLINARY RESEARCH PROCEDURE IN ROMANIA
}

\section{A. N. Puran}

\section{Andra Nicoleta Puran}

Law and Administrative Sciences Faculty, Law and Administrative Sciences Department University of Pitești, Pitești, Romania

*Corespondence: Andra Nicoleta Puran, University of Pitești, Târgul din Vale St., no. 1, Pitești, Romania

E-mail: andradascalu@yahoo.com

\section{Abstract}

Like other professions in Romania the medical profession it is also regulated by special laws: Law no. 95/2006 on medical reform, the Code of Medical Ethics and The Romanian College of Physicians Status. The competent authorities to carry out to carry out disciplinary research of the facts that constitute misconduct and specific procedural rules will be briefly analyzed in this paper.

\section{Key-words: physician, disciplinary responsability, procedure, misconduct}

\section{Introduction}

The sanitary system has suffered a series of modifications and experiments, by the adoption of multiple normative acts amended for several times within the past 10 years, until the adoption of the Law No 95/2006 ${ }^{1}$ on healthcare reform. Neither this law escaped the successive modifications of the provisions covered by it ${ }^{2}$.

Title XII of the Law No 95/2006 on healthcare reform, titled "Practicing medicine. Organization and function of the Romanian College of Physicians" states provisions regarding the disciplinary liability for physicians ${ }^{3}$, as form of the judicial liability ${ }^{4}$ of interest for this paper.

\section{General considerations on the disciplinary liability of physicians}

It was stated that "the disciplinary liability is the most common form of judicial liability of the physician, because it organically derives from the rules of professional conduct, from how each healthcare professional performs his duties. The situations which can involve medical liability are multiple, as well as the medical specialties and means in which the physician can and must offer his services to those in need". 5

Law No 95/2006 on healthcare reform, as framework law, is completed with the provisions stated by the Code of Medical Deontology ${ }^{6}$ and by the statute of the Romanian College of Physicians ${ }^{7}$.

\footnotetext{
${ }^{1}$ Published in the Official Gazette No 372 of 28 April 2006

${ }^{2}$ From the entrance into force until its analysis in this paper, the Law No 95/2006 has suffered 58 modifications, 4 only in 2013.

${ }^{3}$ Section 6, Art 442-451

${ }^{4}$ E. Ciongaru, Teoria generala a dreptului, Scrisul Romanesc Publishing House, Craiova, 2011, p. 150

${ }^{5}$ Doina Popescu, Sănătatea publică-Serviciul public de interes național în dreptul românesc și comparat, University of Bucharest, Law Faculty, Bucharest, 2005, PhD thesis, unpublished, p.185

${ }^{6}$ Annex 2 of the Decision No 2/2012 of the Romanian College of Physicians on the adoption of the Statute and the Code of Medical Deontology of the Romanian College of Physicians, published in the Official Gazette No 298/7 May 2012
} 


\section{A. N. Puran}

Though the Law No 95/2006 does not define the disciplinary misconduct of the physicians, it does mention the sources of law stating obligations for the physicians, without being exhaustive: laws and regulations of the medical profession, the Code of Medical Deontology and the rules for a good professional practice, the Statute of the Romanian College of Physicians, mandatory decisions adopted by the organs of the College of Physicians, as well as any action regarding the profession, committed with guilt ${ }^{8}$ which causes a prejudice for the honor and the prestige of the profession or of the Romanian College of Physicians 9 .

Starting from the framework regulation in this area, Art 94 of the Statute of the Romanian College of Physicians defines the disciplinary misconduct ${ }^{10}$ committed by the physician, stating that it consists in the "misconduct committed with intent violating the oath taken, the laws and regulations specific for the profession of physician, the Code of Medical Deontology, the provisions of the present statute, the mandatory decisions of the Romanian College of Physicians, as well as any other action committed in relation to the profession or outside it, which prejudices the honor and prestige of the profession or of the healthcare system". As it is noticed, the Statute offers a wider area for the sources of the obligations for the physician, enumerating besides the sources stated by the Law No 95/2006 and the oath taken. Likewise, Law No 95/2006 states as disciplinary misconducts only the actions committed in relation to the profession with the purpose of prejudicing the honor and prestige of the profession or of the Romanian College of Physicians, while the Statute expands the object of the misconduct also for the actions which have nothing to do with the profession.

Stated by Art 447 of the Law No 95/2006 on healthcare reform, the disciplinary sanctions applicable for physicians for a disciplinary misconduct committed are restated by the Statute of the Romanian College of Physicians in its Art 100.

As well as in the common law, the principle of a unique disciplinary sanction. Thus, from the provisions of Art 100 Para 1 of the Statute of the Romanian College of Physicians it is deduced that for a disciplinary misconduct can only be applied a single disciplinary sanction, one from the ones listed by the pointed article of law. The sanctions shall be applied considering the gravity of the misconduct, the circumstances, the personal circumstances of the physician and the effects produced by the misconduct.

If a physician repeats the disciplinary misconduct until the sanction is radiated, this is considered as an aggravating circumstance which can be considered in the establishment of the disciplinary sanction for the new misconduct which has been committed ${ }^{11}$. In this regard, according to Art 96 of the Statute of the Romanian College of Physicians, the councils of the territorial colleges must have an evidence of the sanctions applied for their members and to communicate it to the competent institutions.

The disciplinary sanctions applicable for physicians are:

a) Reprimand;

b) Warning;

c) Vote of censure;

d) Fine between 100 lei to 1500 lei;

e) The prohibition to practice medicine or certain medical activities for a period of one month to a year;

f) Withdrawal of the membership of the Romanian College of Physicians.

\footnotetext{
${ }^{7}$ Annex 1 of the Decision No 2/2012 of the Romanian College of Physicians on the adoption of the Statute and the Code of Medical Deontology of the Romanian College of Physicians, published in the Official Gazette No 298/7 May 2012

${ }^{8}$ See E. Ciongaru, op.cit., pp.152-153

${ }^{9}$ According to Art 442 Para 1 of the Law No 95/2006 on healthcare reform

${ }^{10}$ For an analysis of the concept of misconduct see Carmen Nenu, Trăsăturile caracteristice ale contractului individual de muncă, University of Bucharest, Law Faculty, Bucharest, 2008, PhD thesis, unpublished, p. 119

${ }^{11}$ Art 95 of the Statute of the Romanian College of Physicians
} 
a) The reprimand is the mildest sanction which can be applied for physicians, having a preponderant moral feature.

Taken from old labor legislation and kept by the latest normative acts applicable for physicians, the reprimand is a sanction by which the physician is notified that he has violated his professional obligations or prejudiced the honor or prestige of the profession, drawing his attention to the need to review its conduct in the future. This sanction is applicable for all the persons committing a disciplinary misconduct for the first time without serious effects and without intent.

b) The warning is also a measure with a preponderant moral feature. This is an easy sanction without direct material consequences.

The warning is not stated by any of the mentioned normative acts enumerating the disciplinary sanctions, unlike the common law, where the warning must be written.

The warning consists in the notification of the employee about the misconduct committed and is put in mind that if he shall commit new misconducts shall be sanctioned with a more serious penalty. Considering the disciplinary procedural elements, we note that the warning must be written, even if the law does not state so.

c) The vote of censure is a sanction by which an organized collectivity shows its disapproval regarding an unworthy action committed by one of its members or a sanction by which a collectivity, an organization (etc.) disapproves the activity of a leader or of a proxy.

Thus, neither this sanction has direct material consequences for the disciplinary sanctioned physician, only representing a disapproval of the College of Physicians for the action representing a disciplinary misconduct.

d) The only sanction having a direct and prevailing material feature is the fine between 100 lei to 1500 lei.

Though Art 249 Para 1 of the Labor Code states the rule according to which disciplinary fines are prohibited for physicians, both the Law No 95/2006, as well as the Statute of the Romanian College of Physicians settle as sanction the disciplinary fine. Art 100 Para 1 Let d) of the Statute of the Romanian College of Physicians settles both an inferior and a superior limit of the fine. Thus, the fine cannot be less than 100 lei and cannot exceed 1500 lei.

The same legal regulation states the owner of the account where the fine is paid, namely the Romanian College of Physicians. The maximum term in which the fine can be paid is 30 days and starts from the moment when the disciplinary decision is definitive. The failure to comply with this sanction entails another sanction, namely the suspension of the right to practice until the disciplinary fine is paid. The suspension of the right to practice assumes the suspension of all rights and obligations arising from the quality as physician.

e) A more serious misconduct is the prohibition to practice medicine or certain medical activities for a period of one month to a year.

This sanction has two parts: the prohibition to practice medicine and the prohibition to practice certain medical activities.

These disciplinary measures can be instituted for a period of one month to a year, depending on the gravity of the disciplinary misconduct committed.

f) Withdrawal of the membership of the Romanian College of Physicians is the most serious disciplinary sanction applicable to a physician.

Considering that Art 379 Para 1 Let d) of the Law No 95/2006 states that the profession of physician is practiced in Romania by the persons who are members of the Romanian College of Physicians, the withdrawal of this quality assumes the interdiction to practice medicine.

Though this sanction assumes the interdiction to practice medicine, it is not identified with the previous sanction.

The sanction regarding the interdiction to practice medicine or certain medical activities does not assume the withdrawal of the Romanian College of Physicians membership, the sanctioned person keeping his membership to the institution. In exchange, withdrawal of the Romanian College of Physicians membership automatically attracts the interdiction to practice medicine. 


\section{A. N. Puran}

This sanction operates de jure, without being necessary a particular approach of the Romanian College of Physicians, for the time established by a definitive decision of the court regarding the interdiction to practice medicine, when the interdiction is disposed as a complementary measure, and not like a disciplinary sanction.

In the situation of applying this sanction, the sanctioned physician shall be able to submit a new request to recover his membership in the Romanian College of Physicians, with the fulfillment of the legal conditions, after the expiration of the period stated by the court's decision or after 2 years from the moment when the sanction was applied by the disciplinary commission.

The competent authorities to perform the disciplinary investigation are organized by the supreme professional organization of physicians, respectively the Romanian College of Physicians, with its territorial braches.

In the counties and in Bucharest is organized and operates a territorial college of physicians practicing in that administrative-territorial unit.

Territorially, in each college is organized a disciplinary commission which is independent from the college's management, and nationally, the in Romanian College of Physicians is organized the superior discipline commission, also independent from the management.

\section{Disciplinary procedure}

The disciplinary action can be initiated within maximum 6 months since the misconduct is committed or from the moment when prejudicial consequences are known ${ }^{12}$.

The prescription term of 6 months can start from two different moments: from the moment in which the misconduct is committed or from the moment when the prejudicial consequences are known.

The disciplinary investigation organs have not the right to choose between these two moments, but only when the moment when the misconduct was committed in unknown, then they can use the 6 months term from the moment when the prejudicial consequences of the disciplinary misconduct are known.

Thus, if the disciplinary action has not initiated within maximum 6 months from the moment in which the misconduct is committed, though this moment is known, and however fits within the 6 months since the prejudicial consequences are known, the complaint shall be dismissed as late submitted.

Regarding the procedural rules for the performance of the disciplinary action, these are stated by Art 105-117 of the Statute of the Romanian College of Physicians, being governed by the principles stated by Art 54-59 of the Code of Medical Deontology: celerity, presumption of innocence, impartiality, written contradictions, survey.

The disciplinary investigation has three stages performed by different organs within the same territorial college: the bureau of the territorial college registers the notification and verifies the form and the material and territorial competence, the professional county commission performs the disciplinary investigation and the Discipline Commission performs the disciplinary action and issues a decision for the application of a disciplinary sanction.

The intimation regarding a disciplinary misconduct can be made by a complaint or by the own initiative of the authorities.

The complaint shall be submitted to the territorial college in which the physician is a member either personally, by a proxy or by letter with confirmation of receipt. If the complaint is emailed, faxed, submitted or sent in a copy it shall not be taken into consideration.

In order for a complaint to be valid it must cumulatively include all the following elements:

a) Name, surname, address and quality of the plaintiff;

b) Name, surname and working place of the physician against whom is submitted;

c) Physical and moral prejudice caused to the patient;

\footnotetext{
${ }^{12}$ Art 102 Para 1 of the statute of the Romanian College of Physicians
} 
d) The patient's signature.

If the complaint does not include all these validity elements or if it is not submitted or sent according to the law previously analyzed, the plaintiff shall be answered regarding this situation, and his complaint shall be taken into consideration.

The bureau of the territorial college can be notified ex officio and may initiate a disciplinary investigation if is aware of a disciplinary misconduct committed by one of its members.

As a result of the self-notification shall be issued a decision including all the elements that were the basis for the decision being attached, if necessary, all the proper evidences.

After registering the complaint, the bureau of the local college's council shall decide whether it shall or shall not initiate the disciplinary investigation.

The situations for which the disciplinary investigation shall be initiated are strictly and limitative stated by Art 106 Para 2 of the statute of the Romanian College of Physicians:

a) Only if the complaint is not in the competence of the Romanian College of Physicians;

b) When the complaint does not include the mandatory elements above mentioned.

If neither of the two cases is incident, the bureau of the territorial college, by a decision, shall decide the initiation of the disciplinary investigation. The decision shall be communicated to the professional jurisdiction commission from the territorial college. The professional jurisdiction commission shall verify if the notification has been submitted within the 6 months prescription term.

If the notification was made after this term has expired, the professional jurisdiction commission, by a report, shall propose the rejection of the notification as late submitted, without investigating its background. This report and the case file are sent to the disciplinary commission of the territorial college. The discipline commission shall issue a decision for the rejection of the complaint as late submitted, without ruling on the main issue of the matter.

If the complaint is submitted within the term stated by the statute, based on the decision initiating the disciplinary investigation issued by the council's bureau, the professional jurisdiction commission shall inform the aimed physician about the complaint sending him a copy of it, notifying him about the term in which he can submit his defense in written and the term when he must attend the hearing. The physician must submit his defense in written until the term stated in the notification. The disciplinary investigation is similar to the mandatory prior disciplinary investigation from the common law.

Also, for physicians operates the fundamental right to defense. Within the disciplinary investigation the physician has the right to defend himself and to provide evidence supporting it. Medical or forensic units must provide for the disciplinary commissions or the persons assigned with the disciplinary investigation the requested medical documents or any other necessary information, according to Art 102 Para 2 of the statute.

After the disciplinary investigation is concluded, the professional jurisdiction commission shall send the case file together with the proposal to sanction or to drop the disciplinary investigation to the discipline commission of the territorial college. The disciplinary commission has the ability to enforce a disciplinary sanction.

The disciplinary commission shall investigate again, the disciplinary action being supported by the professional jurisdiction commission.

The disciplinary commission shall hear the physician, respecting his right to defense, the witnesses, the plaintiff and shall request the opinion of different specialists in this area.

The solutions that the disciplinary commission may adopt are either to admit the complaint and to apply a disciplinary sanction, or to reject the complaint. The rejection of the complaint and disciplinary action may be settled for two reasons: either the misconduct is not a disciplinary one, or the plaintiff does not attend the hearing settled by the discipline commission or does not state in written his position regarding the request of the commission, or does not attend the survey ordered in the case. For the latter case, even if the misconduct is a disciplinary one, the physician shall not receive a sanction, the disciplinary action being rejected. 


\section{A. N. Puran}

The solution issued by the disciplinary commission shall be included in a decision stating:

a) The number and date of the decision;

b) The composition of the disciplinary commission;

c) Short description of the facts;

d) Presentation of the means of investigation used (declarations of the parties, heard witnesses, investigated documents etc.);

e) The disciplinary sanction applied;

f) The legal ground of its adoption;

g) The term for appeal and where it must be submitted;

h) The signature of the discipline commission's president and his seal;

The decision shall be communicated to the investigated physician, the plaintiff, the executive bureau of the national council of the Romanian College of Physicians and to the professional unit where the physician in working and to the Ministry of Health, if the decision is definitive by no-appeal.

According to Art 117 of the statute is a complaint was submitted against a member of a management organ, the disciplinary investigation shall be solved by the superior discipline commission and gathered by the professional jurisdiction commission of the Romanian College of Physicians.

\section{Appealing the decision for disciplinary sanction}

The term for appeal is 15 calendar days and starts from the moment the decision for disciplinary sanction was communicated.

The owners of the right to appeal are: the sanctioned physicians, the plaintiff, the Ministry of Health, the president of the territorial college and the president of the Romanian College of Physicians. From Art 113 Para 1 of the Statute we deduce that the physician, who has not been sanctioned, regardless of the reason for which the disciplinary action has been stopped, cannot make an appeal against the decision of the disciplinary commission. We consider that if the disciplinary action was dropped based on Art 110 Let c) of the statute of the Romanian College of Physicians, the investigated physician could appeal the decision of the commission based on the fact that the disciplinary action was stopped, if he considers himself to be innocent. This is possible also in the penal law, according to Art 362 Para 2 Let b) of the Code of Criminal Procedure, the defendant being able to appeal against the decision for acquittal or termination of the criminal trial, regarding the grounds of the acquittal or termination.

The appeal is submitted to the territorial disciplinary commission, which shall send it together with the case file, within 3 working days, to the superior disciplinary commission ${ }^{13}$. If the appeals are submitted directly to the superior disciplinary commission these are declared void, according to Art 114 Para 3 of the statute.

The appeal must be written, a condition ad validitatem for it. Also, for the validity of the appeal, it must include the following elements:

a) Name and surname of the objector;

b) The domicile, or headquarters of the objector;

c) The object of the appeal;

d) The motivation of the appeal;

e) The evidences grounding the appeal;

f) The objector's signature.

If the professional jurisdiction commission of the Romanian College of Physicians considers that the appeal does not include all the above elements shall request the objector that, within 5 days from the notification, to complete his appeal.

\footnotetext{
${ }^{13}$ Art 114 Para 1 of the statute has similar provisions with the civil and criminal procedure law, where the requests regarding a mean of appeal are submitted to the court whose decision is appealed.
} 
If the objector does not comply with the request or if the appeal does not include his name, surname, domicile or headquarters, the appeal shall be urgently sent to the superior disciplinary commission with the proposal for rejection.

The appeal has a suspensive effect. From the moment when it was submitted it shall suspend the enforcement of the decision issued by the territorial disciplinary commission.

The appeal cannot include new aspects which have not been invoked in the complaint that led to the initiation of the disciplinary investigation.

In order to solve the appeal, the superior disciplinary commission analyzes the cause under all its aspects. The decision shall be issued after the hearing of the objector and the administration of all evidences considered important for the cause.

The decisions issued by the superior disciplinary commission can either admit or reject the appeal, thus ${ }^{14}$ :

a) It may cancel the decision issued by the territorial disciplinary commission, if it was unlawfully issued and, as a consequence, order the restoration of the territorial disciplinary investigation, according to the law;

b) It may reject the appeal and maintain the provisions of the territorial decisions already issued;

c) It may accept, totally or partially, the appeal and order the annulment, totally or partially, of the territorial decision, ruling on the complaint;

d) It may reject the appeal as unlawfully grounded, if it is not motivated by the objector, or he answered the request to state the reasoning of his appeal.

The decision issued by the superior disciplinary commission must include the same elements as the appealed decision, issued by the territorial disciplinary commission.

Against this decision, the sanctioned physician can submit an action for annulment to the section for the contentious administrative of the tribunal on whose territory he performs his activities. The appeal term is 15 days from the notification of the decision.

\section{Conclusions}

The physicians' disciplinary liability is regulated by the law No 95/2006 on healthcare reform, as framework law, completed with the provisions stated by the Code of Medical Deontology and by the statute of the Romanian College of Physicians.

The specific of physicians' disciplinary liability to the common law results from the facts that constitute misconducts, from the specific sanctions applied to the physicians and also from the disciplinary research procedure.

\section{Bibliography:}

1. E. Ciongaru, Teoria generala a dreptului, "Scrisul Românesc" Publishing House, Craiova, 2011

2. Carmen Nenu, Trăsăturile caracteristice ale contractului individual de muncă, University of Bucharest, Law Faculty, Bucharest, 2008, PhD thesis, unpublished

3. Doina Popescu, Sănătatea publică- Serviciul public de interes național în dreptul românesc şi comparat, University of Bucharest, Law Faculty, Bucharest, 2005, PhD thesis, unpublished

4. Law No $95 / 2006$ on healthcare reform

5. Code of Medical Deontology

6. Statute of the Romanian College of Physicians

\footnotetext{
${ }^{14}$ Art 115 of the statute of the Romanian College of Physicians
} 